\title{
Thermodynamics of intrinsic point defects in non-stoichiometric lead telluride
}

\author{
Dmytro FREIK ${ }^{1}$, Igor GORITCHOK ${ }^{1 *}$, Yuriy LYSYUK ${ }^{1}$, Myroslava SHEVCHUK ${ }^{1}$ \\ ${ }^{1}$ Precarpathian National Vasyl Stefanyk University, Shevchenka St. 57, 76018 Ivano-Frankivsk, Ukraine \\ * Corresponding author. Tel.: +380-34-2596082; e-mail: goritchok@rambler.ru
}

Received July 13, 2011; accepted June 27, 2012; available on-line November 5, 2012

Based on a crystal chemical model for defect subsystems, the equilibrium concentrations of point defects and free charge carriers in PdTe crystals submitted to two-temperature annealing have been calculated as a function of temperature $T$ and tellurium vapor pressure $P_{\mathrm{Te}}$. The technological conditions leading to the formation of materials with n- or p-type conductivity have been determined.

Lead telluride / Two-temperature annealing / Electrical properties / Point defects

\section{Термодинаміка власних точкових дефектів у нестехіометричному плюмбум телуриді}

\author{
Дмитро ФРЕЇК ${ }^{1}$, Ігор ГОРІЧОК ${ }^{1}$, Юрій ЛИСЮК ${ }^{1}$, Мирослава ШЕВЧУК $^{1}$ \\ ${ }^{1}$ Прикарпатський національний університет імені Василя Стефаника, вул. Шевченка 57, \\ 76025 м. Івано-Франківськ, Украӥна \\ * Контактна особа. Тел.: +380-34-2596082; e-mail: goritchok@ rambler.ru
}

На основі запропонованої кристалохімічної моделі дефектної підсистеми розраховано рівноважні концентрації точкових дефектів та вільних носіїв заряду в кристалах РbТе при двотемпературному

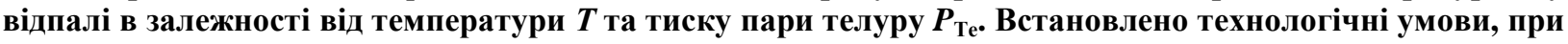
яких формусться матеріал n- або р-типу провідності.

Плюмбум телурид / Двотемпературний відпал / Електричні властивості / Точкові дефекти

Вступ

Серед вузькощілинних напівпровідників плюмбум телурид i тверді розчини на його основі займають особливе місце. 3 одного боку, вони мають ряд унікальних фізико-хімічних властивостей, що робить їх незамінним об'єктом для модельних досліджень, а 3 іншого - широко застосовуються на практиці, зокрема для виготовлення приймачів i когерентних джерел ІЧ-випромінювання спектрального діапазону 3,0-50,0 мкм та термоелектричних пристроїв, що функціонують у інтервалі температур 500-700 К [1-3].

Плюмбум телурид кристалізується у структурі типу $\mathrm{NaCl}$ з параметом гратки $a=6,452 \AA$ [4].
В елементарній комірці міститься 4 октаедричні та 8 тетраедричних порожнин. Ширина забороненої зони РьТе при $T \approx 0$ К становить $E_{\mathrm{g}} \approx 0,19$ еВ [1,2] $(0,18$ [5], 0,187 [6]), збільшується 3 ростом температури зі швидкістю $4 \cdot 10^{-4} \mathrm{eB} / \mathrm{K}$ [2,5-7] і при $T=300 \mathrm{~K} \quad E_{\mathrm{g}}=0,315 \mathrm{eB} \quad[1] . \quad$ При $T \approx 400 \mathrm{~K}$ збільшення ширини забороненої зони припиняється, і ії значення становить $E_{\mathrm{g}} \approx 0,38 \mathrm{eB}$ [8]. Головні екстремуми електронної та діркової зон у плюмбум телуриді розміщені на краю зони Бріллюена у напрямку (111) (точка L). Аналіз концентраційної та температурної залежностей електричних і оптичних властивостей вказує на існування у РbТе другої валентної зони (зони важких дірок) 3 відносно великою ефективною масою (точка $\Sigma$ ). Зона важких дірок вважається 
параболічною, а зона легких дірок описується моделлю Кейна [9]. Енергетична щілина між краями важких $\mathrm{i}$ легких дірок при низьких температурах дорівнює $d E_{V} \approx 0,17 \mathrm{eB}[8]$ i 3 ростом температури зменшується зі швидкістю $\sim 4 \cdot 10^{-4} \mathrm{eB} / \mathrm{K} \quad[6,10-12] \quad\left(d E_{v}(120 \mathrm{~K})=\right.$ $0,12-0,13$ eВ [9], $d E_{v}(300 \mathrm{~K})=0,05-0,08 \mathrm{eB}$ [9]), так що енергетичний проміжок між краями зони провідності і зоною важких дірок залишається незмінним. Отже, при $T>\sim 450 \mathrm{~K}$ заборонена зона плюмбум телуриду стає непрямою. Зростання ролі зони важких дірок при рості температури призводить до збільшення відносної концентрації важких дірок, внаслідок чого зростає середня ефективна маса дірок [13].

Ефективна маса електронів та легких дірок проявляє залежність як від температури [5], так і від концентрації самих носіїв [14]. Температурна залежність ефективної маси для дірок і електронів може бути описана функцією [5]:

$$
m^{*}=m_{0}^{*}\left(\frac{T}{T_{0}}\right)^{\alpha} .
$$

Для концентраційної залежності ефективної маси електронів у роботі [14] запропоновано вираз:

$$
m^{*}=m_{0}^{*}\left(1+\frac{2 \mu}{E_{g}}\right) \text {. }
$$

$\mathrm{PbTe}$ відноситься до сполук із значною областю гомогенності [1]. Відхилення складу від стехіометричного становить $\sim 0,01$ ат. $\% \mathrm{~Pb}$ та $\sim 0,02$ ат.\% Те [4]. Присутність у кристалічній гратці надлишкових атомів одного 3 компонентів зумовлює виникнення значної кількості електроактивних дефектів, основними 3 яких вважаються вакансії та міжвузлові атоми металу i халькогену. Менш ймовірним $\epsilon$ утворення антиструктурних дефектів. Також встановлено, що вакансії халькогену у плюмбум телуриді $\epsilon$ донорами, а вакансії металу акцепторами [15].

У роботі проведено аналіз дефектної підсистеми кристалів РbTe, відпалених у парі телуру, використовуючи метод термодинамічних потенціалів, що базується на розв'язку системи рівнянь рівноваги у двокомпонентній ( $\mathrm{Pb}$ та Те) двофазній (кристал-пара) системі.

\section{Рівняння рівноваги у системі “кристал - пара"}

Ефективно керувати хімічним складом кристалів, a, отже, типом та концентрацією точкових дефектів, можна в процесі двотемпературного відпалу, схема якого представлена на Рис. 1. Відпал зразків проводиться у вакуумованих ампулах в двозонній печі, де одна зона забезпечує температуру кристала, а друга - температуру компонента (Те). Вимірювання температури обох зон проводиться 3 використанням двох термопар, розташованих, відповідно, біля зразка i холоднішого кінця ампули, температура якого i визначає тиск пари телуру $P_{T e}$.

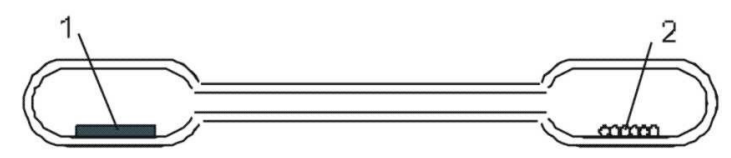

a)

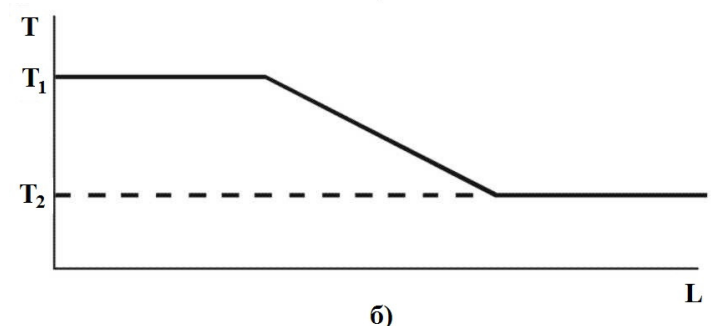

Рис. 1 Схема двотемпературного відпалу (a) і профіль температури (б): 1 - кристал РbTe, 2 - компоненти Те $(\mathrm{Pb})$.

Рівноважні концентрації точкових дефектів (вакансій) у кристалі при двотемпературному відпалі безпосередньо визначали 3 системи рівнянь, що описують рівновагу в гетерогенній багатокомпонентній системі при заданих тиску $P$ i температурі $T$ [16]:

$\mu_{i}^{s}=\mu_{i}^{g}$,

де $\mu_{i}^{s(g)}$ - хімічний потенціал $i$-го компоненту $(i=\mathrm{Pb}, \mathrm{Te})$ у парі $g$ чи кристалі $s$.

Цей метод має ряд переваг перед традиційно використовуваним методом квазіхімічних реакцій Крегера [17], оскільки дозволяє коректно враховувати в моделі електронейтральні дефекти та використовувати вироджену статистику [17]. При розрахунку використано модель вакансій аніонної та катіонної підгратки.

Хімічний потенціал пари [18]:

$\mu^{g}=k T \ln P+\mu_{0}$.

Для одноатомного газу $\mathrm{Pb}$ :

$\mu_{0}=k T\left(-\ln (k T)+\ln \left(h^{3} /(2 \pi m k T)^{\frac{3}{2}}\right)\right) ;$

для двоатомного газу $\mathrm{Te}_{2}$ :

$\mu_{0}=k T\left(-\ln (k T)+\ln \left(h^{3} /(2 \pi m k T)^{\frac{3}{2}}\right)+\right.$

$\left.+\ln \left(h^{2} / 8 \pi^{2} I k T\right)+\ln (h v / k T)\right)$.

де $m$ - маса атома або молекули, $I=m l^{2}-$ момент інерції молекули, $l$ - відстань між ядрами молекули, $v$ - внутрішня частота коливань молекули.

Для визначення хімічних потенціалів дефектів, що дорівнюють хімічному потенціалу компоненту, взятому зі знаком “+” або “-”, у кристалі використовували процедуру диференціювання 
енергії Гіббса $G$ по концентрації дефекту. Енергію Гіббса представляли у вигляді:

$$
\begin{aligned}
& G=G_{0}+\sum\left(E+F_{v i b}\right)[D]+n E_{C}-p E_{V}- \\
& -T\left(S_{n}+S_{p}+S_{k}\right),
\end{aligned}
$$

де $G_{0}-$ енергія Гіббса, що не залежить від присутності дефектів, $E$ - енергія утворення дефекту, $F_{v i b}$ - енергія вільного коливання дефекту, $[D]$ - концентрації дефекту $D, n$ та $p-$ концентрації електронів та дірок, $E_{C}, E_{V}$ - енергії дна зони провідності та стелі валентної зони, $S_{k}$ - конфігураційна ентропія, $S_{n}, S_{p}-$ ентропії електронів у зоні провідності та дірок у валентній зоні. Сумування ведеться по всіх підгратках і всіх дефектах у підгратці.

Енергії однократно та двократно іонізованих дефектів визначаються за формулами:

$E_{1}=E_{0}-\frac{Z}{|Z|} \varepsilon_{1}, \quad E_{2}=E_{0}-\frac{Z}{|Z|}\left(\varepsilon_{1}+\varepsilon_{2}\right)$,

де $E_{0}$ - енергія утворення нейтрального дефекту, $Z$ - зарядовий стан дефекту, $\varepsilon_{1}, \varepsilon_{2}-$ перший та другий рівні іонізації утвореного дефекту.

Зміна енергії вільного коливання для кристалу при утворенні дефекту:

$$
F_{v i b}= \pm\left\{3 k T \ln \left(\frac{T_{\theta}}{T}\right)-k T\right\}+x \cdot 3 k T \ln \left(\frac{\omega}{\omega_{0}}\right) .
$$

Тут $x$ - кількість атомів що змінили частоту своїх коливань $3 \omega_{0}$ на $\omega$.

Ентропію визначали за законом Больцмана:

$$
S_{k}=k \ln \left(\prod W_{j}\right)=\sum k \ln \left(W_{j}\right)=\sum S_{j},
$$

де $W_{j}$ - термодинамічна ймовірність $j$-ї підгратки. Для підгратки з кількома різними видами дефектів:

$$
W_{j}=\frac{N_{J} !}{\left(N_{J}-\sum[D]\right) ! \prod[D] !},
$$

де $N_{J}-$ концентрація вузлів, у яких може утворитися дефект.

При температурах відпалу $(T \geq 800 \mathrm{~K})$ зона важких дірок знаходиться вище зони легких дірок, тому вважатимемо, що основний внесок у концентрацію дірок роблять важкі дірки. Для електронів та важких дірок термодинамічні ймовірності дорівнюють:

$$
W_{n}=\frac{N_{C} !}{\left(N_{C}-n\right) ! n !}, \quad W_{p}=\frac{N_{V} !}{\left(N_{V}-p\right) ! p !},
$$

де $N_{C}, N_{V}$ - густина станів у зоні провідності та валентній зоні, відповідно.

Концентрації електронів та важких дірок можуть бути розраховані за формулами:

$$
\begin{aligned}
& n=\left(\frac{2 \pi m_{e}^{*} k T}{h^{2}}\right)^{\frac{3}{2}} a \mathrm{e}^{b \frac{\mu}{k T}}, \\
& p=\left(\frac{2 \pi m_{h}^{*} k T}{h^{2}}\right)^{\frac{3}{2}} a \mathrm{e}^{-b \frac{\mu+E_{g}}{k T}},
\end{aligned}
$$

де коефіцієнти $a$ та $b$ - поправки, що враховують ступінь виродження носіїв i вираховуються чисельно при апроксимації інтеграла Фермі, $E_{g}$ ширина забороненої зони.

Враховуючи, що ефективна маса електронів залежить від їх концентрації за законом $m=m_{e, 0}^{*}(0) \cdot\left(1+2 \mu / E_{g}\right)$ з роботи [14], матимемо:

$n=\left(\frac{2 \pi m_{e, 0}^{*} k T}{h^{2}}\right)^{\frac{3}{2}} a \mathrm{e}^{b \frac{\mu}{k T}}\left(1+\frac{2 \mu}{E_{g}}\right)^{\frac{3}{2}}$.

Хімічний потенціал електронів $\mu$ визначали 3 рівняння електронейтральності, яке для високих температур може бути записане у вигляді:

$$
\begin{aligned}
& \sum Z[D]=\left(\frac{2 \pi m_{e, 0}^{*} k T}{h^{2}}\right)^{\frac{3}{2}} a \mathrm{e}^{b \frac{\mu}{k T}}\left(1+\frac{2 \mu}{E_{g}}\right)^{\frac{3}{2}}- \\
& -\left(\frac{2 \pi m_{h}^{*} k T}{h^{2}}\right)^{\frac{3}{2}} a \mathrm{e}^{-b \frac{E_{g}+\mu}{k T}} .
\end{aligned}
$$

Сумування проводиться по всіх іонізованих дефектах.

У такому вигляді рівняння (15) не може бути розв'язане аналітично, тому для спрощення цієї задачі експериментальні дані [14] були апроксимовані функцією:

$$
\frac{m^{*}}{m_{e, 0}^{*}}=\alpha n^{\beta}=0,111 \cdot 10^{-6} \cdot n^{\frac{1}{3}} \text {. }
$$

Враховуючи (16):

$$
\begin{aligned}
& n=a \cdot\left(\frac{2 \pi m_{e, 0}^{*} k T}{h^{2}}\right)^{\frac{3}{2}} \cdot\left(\alpha n^{\frac{1}{3}}\right)^{\frac{3}{2}} \cdot \mathrm{e}^{b \frac{\mu}{k T}}= \\
& =a \cdot\left(\frac{2 \pi m_{e, 0}^{*} k T}{h^{2}}\right)^{\frac{3}{2}} \cdot \alpha^{\frac{3}{2}} \cdot n^{\frac{1}{2}} \cdot \mathrm{e}^{b \frac{\mu}{k T}},
\end{aligned}
$$

або $n=N_{C} \cdot a \mathrm{e}^{b \frac{\mu}{k T}}$.

Тут

$$
\begin{aligned}
& N_{C}=a \cdot N_{C, 0}^{2} \cdot \alpha^{3} \cdot \mathrm{e}^{b \frac{\mu}{k T}}, \\
& N_{C, 0}=\left(\frac{2 \pi m_{e, 0}^{*} k T}{h^{2}}\right)^{\frac{3}{2}} .
\end{aligned}
$$

Тоді рівняння електронейтральності матиме вигляд:

$$
\sum_{\text {Звідки }} Z D=\alpha^{3} a^{2} N_{C, 0}^{2} \mathrm{e}^{2 b \frac{\mu}{k T}}-a \cdot N_{V} \mathrm{e}^{-b \frac{E_{g}+\mu}{k T}} .
$$

$$
\mu=\frac{1}{b} \cdot k T \cdot \ln \left(\begin{array}{l}
\frac{1}{6}\left\{108 B+12 \sqrt{-12 A^{3}+81 B^{2}}\right\}^{3}+ \\
+2 A\left\{108 B+12 \sqrt{-12 A^{3}+81 B^{2}}\right\}^{\frac{1}{3}}
\end{array}\right),
$$


де

$$
\begin{gathered}
A=\frac{\sum Z D}{\alpha^{3} a^{2} N_{C, 0}^{2}}, \\
B=\frac{a N_{V} \mathrm{e}^{-b \frac{E_{g}}{k T}}}{\alpha^{3} a^{2} N_{C, 0}^{2}} .
\end{gathered}
$$

Тоді хімічний потенціал дефекту:

$$
\begin{aligned}
& \mu_{D_{i}}^{s}=E_{i}+F_{v i b, i}-k T \ln \left(\frac{N_{J}-\sum[D]}{[D]}\right)+ \\
& +\left[2 n\left(\begin{array}{l}
\left.E_{C}-k T\left(\ln \frac{N_{C}-n}{n}-\frac{N_{C}}{2 n} \ln \frac{N_{C}-n}{N_{C}}\right)+\right) \\
+p\left(E_{V}+k T\left(\ln \frac{N_{V}-p}{p}\right)\right)
\end{array}\right) \times \times\right.
\end{aligned}
$$

$\times \frac{b}{k T} \frac{d \mu}{d D}$

Отже, для розрахунку рівноважної концентрації точкових дефектів при двотемпературному відпалі розв'язується система рівнянь типу (3), в якій хімічні потенціали визначаються 3 рівнянь (4) та (23). Кожне таке рівняння записується для всіх точкових дефектів, що присутні у кристалі. Систему рівнянь розв'язували шляхом мінімізації квадратичної функції від нев'язок за допомогою математичного пакету MAPLE.

\section{Енергії утворення та іонізації точкових дефектів}

Енергії іонізації дефектів приймались рівними значенням, отриманим у роботі [19]. Зокрема, встановлено, що положення рівнів заселеності вакансій визначаються міжелектронною взаємодією. Остання враховувалась у рамках обмеженого наближення Хартрі-Фока. Виявилось, що міжелектронна взаємодія сильно трансформує раніше запропоновану модель Паради і Пратта [15]. Так, наприклад, $\mathrm{V}_{\mathrm{Pb}}$ у $\mathrm{PbTe}$ призводить до виникнення енергетичного рівня у забороненій зоні, який відсутній в одноелектронній теорії. Незначною варіацією параметрів моделі можна досягнути точного співпадання рівня заселеності вакансії плюмбуму 3 відомим експериментальним значенням на 75 меВ нижче зони провідності плюмбум телуриду [18]. Експеримент також вказує на акцепторний характер цього рівня [19].

Основний результат розрахунку, проведеного у роботі [19] без змінних параметрів, полягає в тому, що він передбачає існування рівнів перезарядки вакансій в $\mathrm{A}^{4} \mathrm{~B}^{6}$ поблизу країв дозволених зон. Визначений у роботі [19] рівень $E_{C}-0,075$ еВ відповідає переходу $\mathrm{V}_{\mathrm{Pb}} \quad 3$ однократного в двократний акцепторний стан, а рівень $E_{C}+\sim 0,2$ еВ - переходу $\mathrm{V}_{\mathrm{Te}} 3$ однократного в двократний донорний стан. Рівні нейтральних станів вакансії металу $E_{V}-\sim 0,8 \mathrm{eB}$ і вакансії халькогену $E_{C}+\sim 0,7$ еВ лежать далеко від країв забороненої зони.

Варто зазначити, що у роботі [7] методом низькотемпературної калориметричної спектроскопії в полікристалічних зразках n-PbTe 3 незначним ( 0,1 ат.\%) надлишком плюмбуму виявлена $\delta$-подібна особливість у густині станів зони провідності, інтерпретована як вузька ( 0,01 еВ) смуга резонансних станів, пов'язаних 3 вакансійними дефектами у аніонній підгратці. Оцінка енергетичного положення вакансійного рівня над краєм зони провідності на основі даних про залежність $\varepsilon_{F}(n)$ для РbTе при $T=77 \mathrm{~K}$ дає величину $E_{V}(\mathrm{Te})=165 \pm 15 \mathrm{meB}$, що добре узгоджується з результатами розрахунку [19].

При розрахунку концентрацій точкових дефектів, вважали, що 3 ростом температури енергія іонізації дефекту зростає пропорційно збільшенню відстані між зоною провідності та зоною легких дірок.

Енергії утворення точкових дефектів були прийняті рівними значенням, отриманим у роботі [20] $\quad\left(E\left(\mathrm{~V}_{\mathrm{Pb}}\right)=2,48 \mathrm{eB}, \quad E\left(\mathrm{~V}_{\mathrm{Te}}\right)=1,94 \mathrm{eB}\right), \quad$ які водночас $є$ близькими до значень, отриманих у роботі [21] $\left(E\left(\mathrm{~V}_{\mathrm{Pb}}\right)=2,187 \mathrm{eB}, E\left(\mathrm{~V}_{\mathrm{Te}}\right)=2,135 \mathrm{eB}\right)$. Проте, такий вибір не дозволив кількісно правильно пояснити експериментальні дані. Тому значення енергій утворення вважали варіаційним параметром. Також варіаційними параметрами вважали зміни частот коливань атомів в околі дефектів, оптимальні значення яких приведені в Таблиці 1.

Таблиця 1 Енергетичні параметри точкових дефектів у кристалах $\mathrm{PbTe.}$

\begin{tabular}{c|c|c}
\hline & $\mathrm{V}_{\mathrm{Pb}}$ & $\mathrm{V}_{\mathrm{Te}}$ \\
\hline$E_{0}, \mathrm{eB}$ & 4,18 & 3,19 \\
$\varepsilon_{1}, \mathrm{eB}[18]$ & $E_{C}-0,075$ & $E_{C}+0,165$ \\
$\varepsilon_{2}, \mathrm{eB}[18]$ & $E_{V}-0,8$ & $E_{C}+0,7$ \\
$x$ & 6 & 6 \\
$\omega / \omega_{0}$ & 2,90 & 4,00 \\
\hline
\end{tabular}

\section{Обговорення результатів дослідження}

Розраховані концентрації точкових дефектів в залежності від температури відпалу $T$ та

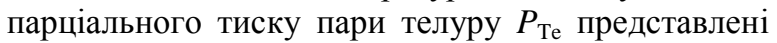
на Рис. 2-4. Параметри, що при цьому використовувались наведено в Таблиці 2. Як видно (Рис. 2,4), теоретично визначені концентрації вільних носіїв задовільно описують експериментальні дані. Для порівняння, на Рис. 3 приведено залежності концентрацій дефектів, вільних електронів і дірок від тиску пари телуру, отримані 3 використанням моделі у якій не 
Таблиця 2 Основні параметри кристалів PbTe.

\begin{tabular}{l|l|c}
\hline \multicolumn{1}{c|}{ Параметр } & \multicolumn{1}{|c}{ Значення } & Література \\
\hline Внутрішня частота коливань молекули $\mathrm{Te}_{2}$ & $0,625102 \cdot 10^{13} \mathrm{c}^{-1}$ & {$[22]$} \\
Відстань між ядрами у молекулі Те & \\
Константа $K=P_{\mathrm{Te}_{2}}^{1 / 2} P_{\mathrm{Pb}}$ & $2,59 \cdot 10^{-10} \mathrm{M}$ & {$[22]$} \\
$E_{g}(0<T<300), \mathrm{eB}$ & $K=10^{(-17720 / T+9,54)} \cdot(101325)^{3 / 2} \Pi^{3 / 2}$ & {$[23]$} \\
$E_{g}(T>400), \mathrm{eB}$ & $0,18+4 \cdot 10^{-4} \cdot T$ & {$[5]$} \\
Ефективна маса електронів & 0,38 & {$[11]$} \\
Ефективна маса легких дірок & $0,142 \cdot m_{0} \cdot(T / 120)^{0,4}$ & {$[5]$} \\
Ефективна маса важких дірок & $0,142 \cdot m_{0} \cdot(T / 120)^{0,4}$ & {$[5]$} \\
Температура Дебая & $1,10 \cdot m_{0}$ & {$[10]$} \\
\hline
\end{tabular}

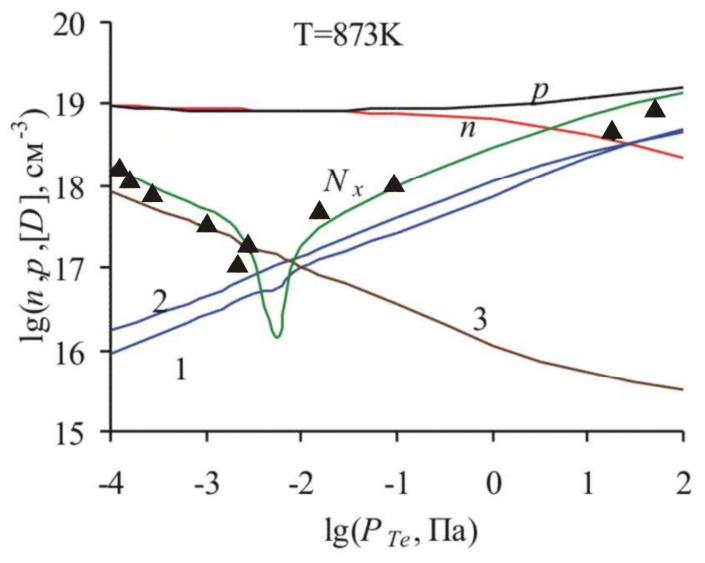

(a)

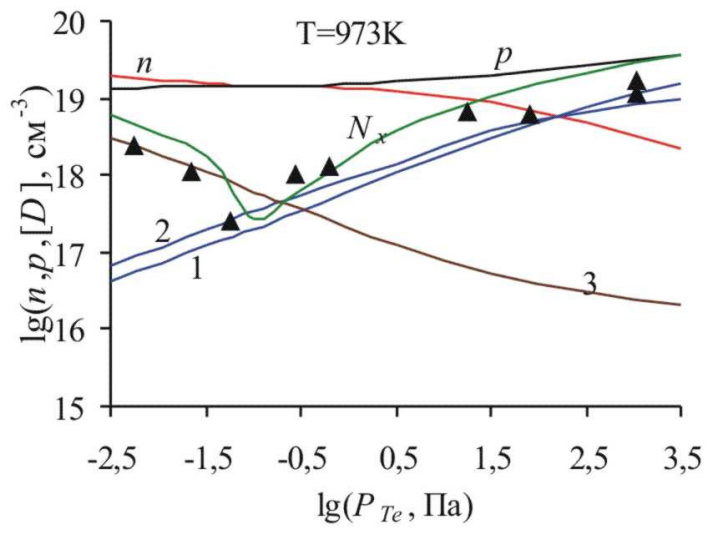

(B)

враховано концентраційну залежність ефективної маси електронів $m_{e}^{*}(n)$. Видно, що в цьому випадку концентрації донорних дефектів та вільних електронів є меншими, аніж у випадку використання моделі, в якій ця залежність врахована.

Згідно з проведеним розрахунком, в матеріалі насиченому плюмбумом домінуючими дефектами $\epsilon$ двократно іонізовані вакансії телуру $\left(\mathrm{V}_{\mathrm{Te}}^{2+}\right)$, а насиченому телуром - однократно i двократно

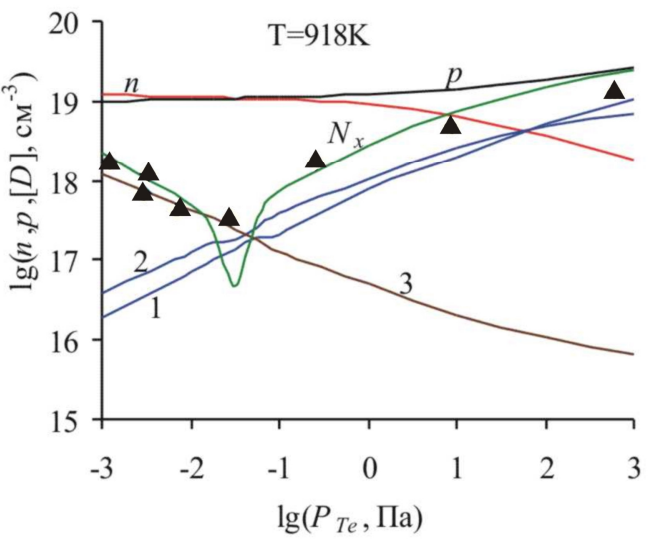

(б)

Рис. 2 Залежність концентрації електронів $n$, дірок $p$, холлівської концентрації $N_{x}$ i точкових дефектів $[D]\left(1-\mathrm{V}_{\mathrm{Pb}}^{-1}, 2-\mathrm{V}_{\mathrm{Pb}}^{-2}\right.$, $3-\mathrm{V}_{\mathrm{Te}}^{+2}$ ) для РbТе від тиску пари телуру $P_{\mathrm{Te}}$ при двотемпературному відпалі за температур $T, \quad$ K: 873 (а), 918 (б), 973 (в). Криві розрахунок, $\boldsymbol{\Delta}$ - експеримент [5].

іонізовані вакансії плюмбуму $\left(\mathrm{V}_{\mathrm{Pb}}^{-}, \mathrm{V}_{\mathrm{Pb}}^{2-}\right)$. При сталій температурі відпалу із зростанням тиску пари телуру концентрація двократно заряджених вакансій плюмбуму $\mathrm{V}_{\mathrm{pb}}^{2-}$ збільшується швидше ніж однократно заряджених вакансій $\mathrm{V}_{\mathrm{Pb}}^{-}$, таким чином, що в околі n-p-переходу домінуючими $\epsilon$ $\mathrm{V}_{\mathrm{Pb}}^{2-}$. а при максимальному тиску пари телуру $\mathrm{V}_{\mathrm{Pb}}^{-}$. Концентпації нейтпальних вакансій плюмбуму $\quad \mathrm{V}_{\mathrm{Pb}}^{0} \quad$ та телуру $\mathrm{V}_{\mathrm{Te}}^{0} \mathrm{i}$ однократно іонізованих вакансій телуру $\mathrm{V}_{\mathrm{Te}}^{1+} \quad \epsilon \quad$ набагато 
меншими, тому ці залежності не приведені на Рис. 2-4. Варто зазначити, що за умови справедливості прийнятої моделі розташування енергетичних рівнів вакансій, для того щоб концентрації нейтральних дефектів були співвимірними 3 концентраціями іонізованих, необхідно щоб рівень Фермі знаходився глибоко у дозволених зонах: $E_{V}-\sim 0,8 \mathrm{eB}$ - для вакансії плюмбуму, $E_{C}+\sim 0,7$ еВ - для вакансії телуру.

Оскільки досягнути такого виродження практично неможливо, то при розрахунку дефектної підсистеми можна використовувати моделі, що не враховують нейтральних дефектів.

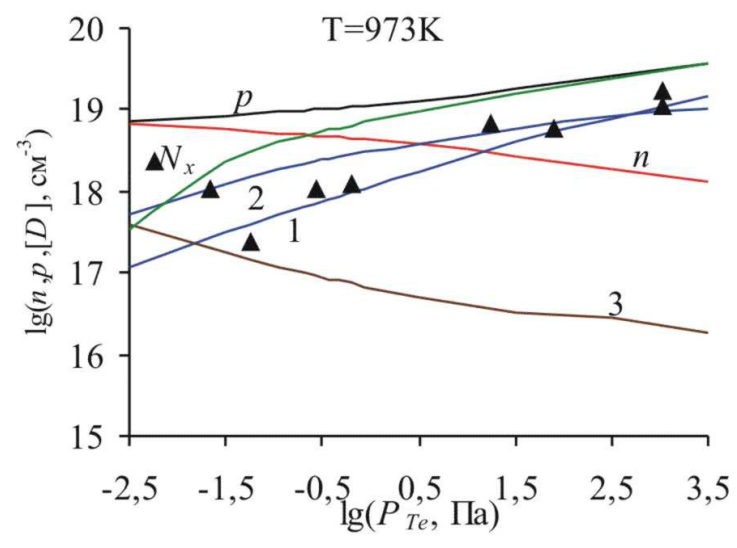

Рис. 3 Залежність концентрації електронів $n$, дірок $p$, холлівської концентрації $N_{x}$ i точкових дефектів [D] $\left(1-\mathrm{V}_{\mathrm{Pb}}^{-1}, 2-\mathrm{V}_{\mathrm{Pb}}^{-2}\right.$, $3-\mathrm{V}_{\mathrm{Te}}^{+2}$ ) для РbТе від тиску пари телуру $P_{\mathrm{Te}}$ при двотемпературному відпалі за температури $T=973 \mathrm{~K}, \quad$ отримана 3 використанням моделі в якій не враховано залежність $m_{e}^{*}(n)$. Криві - розрахунок, $\boldsymbol{\Delta}-$ експеримент [5].

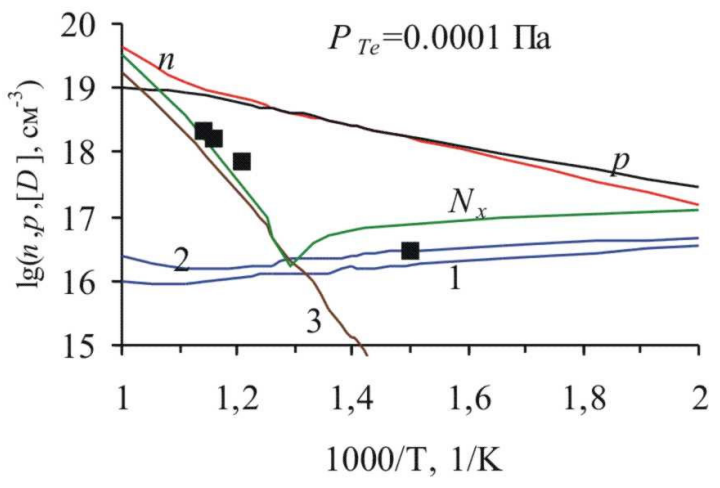

Рис. 4 Залежність концентрації електронів $n$, дірок $p$, холлівської концентрації $N_{x}$ i точкових дефектів [D] $\left(1-\mathrm{V}_{\mathrm{Pb}}^{-1}, 2-\mathrm{V}_{\mathrm{Pb}}^{-2}\right.$, $3-\mathrm{V}_{\mathrm{Te}}^{+2}$ ) для РbТе від температури відпалу $T$ за тиску пари телуру $P_{\mathrm{Te}}=10^{-4}$ Па. Криві розрахунок, - експеримент [5].
Отримані при моделюванні більші значення енергій утворення дефектів, у порівнянні 3 літературними даними, можуть бути пояснені особливостями електронної підсистеми кристалів плюмбум телуриду, що не завжди вдається врахувати при розрахунках. Так, зокрема, прості моделі на зразок [20], що використовувались при обчисленні енергій утворення вакансій, не враховують спін-орбітальної взаємодії, яка $\epsilon$ суттєвою у кристалах PbTe [24]. Також при розрахунках не враховано деформацій гратки в околі дефектів, зумовлених ефектом Яна-Тейлора $[1,19]$, що також може суттєво (на кілька десятих електрон-вольт) змінити енергію утворення іонізованих дефектів. Проте, запропонована модель досить точно описує дані холлівських вимірювань, що може бути підтвердженням iі адекватності.

\section{Висновки}

1. Запропоновано кристалохімічну модель дефектної підсистеми плюмбум телуриду, яка враховує вакансії у аніонній $\left(\mathrm{V}_{\mathrm{Te}}^{0}, \mathrm{~V}_{\mathrm{Te}}^{+}, \mathrm{V}_{\mathrm{Te}}^{2+}\right)$ та катіонній $\left(\mathrm{V}_{\mathrm{Pb}}^{0}, \mathrm{~V}_{\mathrm{Pb}}^{-}, \mathrm{V}_{\mathrm{Pb}}^{2-}\right)$ підгратках, кожна з яких може знаходитись у трьох зарядових станах: нейтральному, однократно або двократно зарядженому, відповідно.

2. Встановлено, що в матеріалі насиченому плюмбумом домінуючими дефектами $є$ двократно іонізовані вакансії телуру $\left(\mathrm{V}_{\mathrm{Te}}^{2+}\right)$, а насиченому телуром - однократно i двократно іонізовані вакансії плюмбуму ( $\left.\mathrm{V}_{\mathrm{Pb}}^{-}, \mathrm{V}_{\mathrm{Pb}}^{2-}\right)$.

3. Для якісно правильного пояснення експериментальних залежностей холлівської концентрації необхідним $є$ врахування у моделі температурної і концентраційної залежностей ефективних мас електронів та легких дірок.

4. Теоретично розраховані концентрації вільних носіїв струму у кристалах РbTе задовільно узгоджуються 3 даними холлівських вимірювань у широкому інтервалі технологічних параметрів, що свідчить про адекватність запропонованої моделі точкових дефектів.

Робота виконана згідно з науковими проектами МОН України (державні реєстраційні номери: 0111U001766, 0110U000144) та Державного агентства з питань науки, інновацій та інформатизачії Украӥни (державний реєстраційний номер: 0110U007674). 


\section{Література}

[1] Д.М. Заячук, Физ. тех. полупроводн. 31(2) (1997) 1692-1713.

[2] В.И. Кайданов, Ю.И. Равич, Усn. физ. наук 145(1) (1985) 51-86.

[3] В.М. Шперун, Д.М. Фреїк, Р.І. Запухляк, Термоелектрика плюмбум телуриду та його аналогів, Плай, Івано-Франківськ, 2000, 250 с.

[4] Д.М. Фреїк, В.В. Прокопів, М.О. Галущак, М.В. Пиц, Г.Д. Матеїк, Кристалохімія $i$ термодинаміка дефектів у сполуках $A^{I V} B^{V I}$, Плай, Івано-Франківськ, 1999, 164 с.

[5] Д.Б. Чеснокова, М.И. Камчатка, Неорг. матер. 37(2) (2001) 157-164.

[6] С.А. Немов, Ю.И. Равич, Усn. Физ. Наук 168(8) (1998) 817-842.

[7] И.А. Черник, А.В. Березин, С.Н. Лыков, Е.П. Сабо, Ю.Д. Титаренко, Письма ж. эксп. теор. физ. 48(10) (1988) 550-553.

[8] Y. Matsushita, Thesis, Stanford University, 2007.

[9] И.К. Смирнов, Ю.И. Уханов, Физ. тех. полупроводн. 3(12) (1969) 1833-1836.

[10] М.И. Виноградова, В.И. Тамарченко, Л.В. Прокофьева, Физ. тех. полупроводн. 9(3) (1975) 483-487.

[11] Б.Ф. Грузинов, И.А. Драбкин, Г.Ф. Захарюгина, А.В. Матвеенко, И.В. Нельсон, Физ. тех. полупроводн.13(2) (1979) 330-334.
[12] Л.В. Прокофьева, Д.А. Пшенай-Северин, П.П. Константинов, А.А. Шабалдин, Физ. тех. полупроводн. 43(9) (2009) 1195-1198.

[13] Г.А. Ахмедова, Г.З. Багиева, Н.Б. Мустафаев, З.Ф. Агаев, Fizika XIII(1-2) (2007) 157-159.

[14] И.Н. Дубровская, Ю.И. Равич, Физ. тверд. тела 8(5) (1966) 1455-1460.

[15] N.J. Parada, G.W. Pratt, Phys. Rev. Lett. 22(5) (1969) 180-182.

[16] В.К. Семенченко, Избранные главы теоретической физики, Просвещение, Москва, 1966, 396 с.

[17] В.И. Кайданов, С.А. Немов, Ю.И. Равич, Физ. тех. полупроводн. 28(3) (1994) 369-393.

[18] Ю.Б. Румер, М.Ш. Рывкин, Термодинамика, статистическая физики и кинетика, Наука, Москва, 1972, 400 с.

[19] О.А. Панкратов, П.П. Поваров, Физ. тверд. тела 30(3) (1988) 880-882.

[20] В.В. Прокопів, І.В. Горічок Л.Д. Юрчишин, Фіз. хім. тв. тіла 11(4) (2010) 849-852.

[21] H. Khang, S.D. Mahanti, J. Puru, Phys. Rev. B 76 (2007) 115432-1-18.

[22] Ф. Крегер, Химия несовериенных кристаллов, Мир, Москва, 1972, 640 с.

[23] В.П. Зломанов, А.В. Новоселова, P-T-xдиаграммы состояния системь металлхалькоген, Наука, Москва, 1987, 208 с.

[24] Б.А. Волков, О.А. Панкратов, А.В. Сазонов, Физ. тех. полупроводн. 16(10) (1982) 1734-1742. 